\title{
Burrowing Parrots Cyanoliseus patagonus as Long-Distance Seed Dispersers of Keystone Algarrobos, Genus Prosopis, in the Monte Desert
}

\author{
Guillermo Blanco ${ }^{1, *(\mathbb{D})}$, Pedro Romero-Vidal ${ }^{2}$, Martina Carrete ${ }^{2}\left(\mathbb{D}\right.$, Daniel Chamorro ${ }^{3}\left(\mathbb{D}\right.$, Carolina Bravo $^{4}$, \\ Fernando Hiraldo ${ }^{5}$ (D) and José L. Tella ${ }^{5}$
}

check for updates

Citation: Blanco, G.; Romero-Vidal, P.; Carrete, M.; Chamorro, D.; Bravo, C.; Hiraldo, F.; Tella, J.L. Burrowing Parrots Cyanoliseus patagonus as Long-Distance Seed Dispersers of Keystone Algarrobos, Genus Prosopis, in the Monte Desert. Diversity 2021, 13, 204. https://doi.org/10.3390/ d13050204

Academic Editor: Luc Legal

Received: 24 April 2021

Accepted: 10 May 2021

Published: 12 May 2021

Publisher's Note: MDPI stays neutral with regard to jurisdictional claims in published maps and institutional affiliations.

Copyright: (c) 2021 by the authors. Licensee MDPI, Basel, Switzerland. This article is an open access article distributed under the terms and conditions of the Creative Commons Attribution (CC BY) license (https:/ / creativecommons.org/licenses/by/ $4.0 /)$.
1 Department of Evolutionary Ecology, Museo Nacional de Ciencias Naturales CSIC, 28006 Madrid, Spain

2 Department of Physical, Chemical and Natural Systems, Universidad Pablo de Olavide, Carretera de Utrera, km 1, 41013 Sevilla, Spain; pedroromerovidal123@gmail.com (P.R.-V.); mcarrete@upo.es (M.C.)

3 Departamento de Ciencias Ambientales, Universidad de Castilla-La Mancha, Av. Carlos III s/n, 45071 Toledo, Spain; daniel.chamorro.cobo@gmail.com

4 Centre d'Etudes Biologiques de Chizé, UMR 7372, CNRS and La Rochelle Université, F-79360 Beauvoir-sur-Niort, France; carolina.bravo.parraga@gmail.com

5 Department of Conservation Biology, Estación Biológica de Doñana CSIC, 41092 Sevilla, Spain; hiraldo@ebd.csic.es (F.H.); tella@ebd.csic.es (J.L.T.)

* Correspondence: g.blanco@csic.es

\begin{abstract}
Understanding of ecosystem structure and functioning requires detailed knowledge about plant-animal interactions, especially when keystone species are involved. The recent consideration of parrots as legitimate seed dispersers has widened the range of mechanisms influencing the life cycle of many plant species. We examined the interactions between the burrowing parrot Cyanoliseus patagonus and two dominant algarrobo trees (Prosopis alba and Prosopis nigra) in the Monte Desert, Argentina. We recorded the abundance and foraging behaviour of parrots; quantified the handling, consumption, wasting, and dispersal of ripe and unripe pods; and tested the viability of soft and hard ripe seeds wasted and transported by parrots. We found a high abundance of burrowing parrots. They predated on soft seeds from unripe pods while exclusively feeding upon pulp wrapping hard seeds from ripe pods. Frequent pod wasting beneath the plant or transport at a distance invariably implied the dispersal of multiple seeds in each event. Moreover, soft seeds retained viability after desiccation outside the mother plant, suggesting effective seed dispersal after partial pod predation due to a predator satiation effect. In about half of the foraging flocks, at least one parrot departed in flight with pods in its beak, with $10-34 \%$ of the flock components moving pods at distances averaging $238 \mathrm{~m}$ (P. alba) and $418 \mathrm{~m}$ (P. nigra). A snapshot sampling of faeces from livestock and wild mammals suggested a low frequency of seed dispersal by endozoochory and secondary dispersal by ants and dung beetles. The nomadic movements and long flights of burrowing parrots between breeding and foraging sites can lead to the dispersal of huge amounts of seeds across large areas that are sequentially exploited. Further research should evaluate the role of the burrowing parrot as a functionally unique species in the structure of the Monte Desert woods and the genetic structure of algarrobo species.
\end{abstract}

Keywords: algarrobo; drylands; High Monte; parrots; seed dispersal; soft seed viability; stomatochory

\section{Introduction}

Dry forests are among the most threatened ecosystems worldwide due to direct habitat destruction and fragmentation by fire, overexploitation for fuelwood, and agriculture [1,2]. Livestock ranching has exerted a predominant impact for decades on the loss and trampling of vegetation, alteration of nutrient cycles, and competition with wild plant consumers [3-5]. These impacts are increasingly disrupting many ecological interactions of vital importance for the composition, structure, and functioning of dry ecosystems [5-8], even before they 
are known and properly understood [9]. Livestock often alter seed dispersal of the plants they feed on, favouring some species over others and disturbing native plant-animal interactions with a function in seed dispersal $[5,8,10]$. These threats, together with hunting for bush meat, are reducing populations of wild species that interact with the remaining vegetation in multiple ways $[1,2,5,8]$. Among them, there are several vertebrate groups that have been long neglected or understudied for their seed dispersal function in drylands, including parrots, rodents, carnivore and ungulate mammals, and reptiles [5,7,11-16]. This has contributed to sustaining the old controversy on the role of extinct megafauna as legitimate dispersers of many large-fruited plants [17], which has led to the proposal of domestic ungulates as contemporary substitutes conducting this ecological function [18]. The megafauna syndrome hypothesis gained momentum in the last few decades, but recent research has increasingly challenged its foundations by incorporating overlooked dispersers into seed dispersal webs and by considering ectozoochory in addition to endozoochory (e.g., [8,14,16,19-22]).

Legume trees (Fabaceae) constitute the dominant woody layer of many drylands in America [1,2] and have been exploited by human populations for millennia [23]. In particular, algarrobos (genus Prosopis, Mimosoideae, Leguminosae) are numerically-, biomass-, and functionally-dominant species intensively exploited for fruits by wild animals, livestock, and humans $[24,25]$. Because of the presence of a sweet pulp covering the seeds inside relatively large pods, dispersal has been mostly attributed to endozoochorous syndromes involving extant native and non-native mammals $[26,27]$ and extinct megafauna in the past [17]. External short-distance dispersal by ants (myrmecochory) and potentially dung beetles $[28,29]$ and stomatochory and seed hoarding by rodents $[29,30]$ have also been highlighted. However, molecular reconstructions suggest long-distance dispersal by birds as the most likely hypothesis to explain the phylogeography and population genetics of the genus Prosopis and other legumes in America [31,32]. This conflicts with the assumption that avian species exploiting algarrobos and other legume pods are exclusive seed predators [28,33], or short-distance dispersers, in the case of flightless greater rhea (Rhea americana) [34,35]. On the contrary, recent research has highlighted parrots as seed dispersers of legumes, including several Prosopis species [13,36]. This role may be especially evident and relevant in ecological terms in dry ecosystems with avian frugivore richness lower than expected from overall bird diversity [Kissling et al., 2009] and in the absence of other avian long-distance dispersers, as documented in the dry tropical forest of the inter-Andean valleys $[13,37]$.

Algarrobo seeds show physical dormancy, an adaptation to germinate when the environmental conditions are optimal after the erosion of the external hard coat by factors like temperature, sunlight, and soil abrasion $[27,38,39]$. This process has also been assumed to be a seed adaptation to resist the chemical and abrasive action of the digestive tract of mammals without losing seed viability while influencing germinability, depending on both legume and consumer species [27,40,41]. Seeds of legumes and other plants may retain viability and can germinate even when fruits end ripening - and seed desiccationseparated from the mother plant (generally termed after-ripening) during the final fruiting stage [42-46]. This implies that the transport of unripe fruits with viable seeds completely formed but not entirely dried and hardened (hereafter, soft seeds) could be considered effective for seed dispersal. This remains a largely overlooked mechanism, with implications in dispersal ecology [47]. To our knowledge, this possibility has been scarcely evaluated for its potential influence in seed dispersal by animals handling unripe fruits [48]. In addition, most experiments on viability and germinability after mammal gut passage have been conducted in laboratory and greenhouse conditions, thus often obviating the critical stage between seed handling by consumers and dispersal and germination in natural conditions.

The recent consideration of parrots as key seed dispersers by multiple and complementary mechanisms, including the wasting and transport of ripe and unripe fruits, have widened the range of mechanisms influencing the life cycle of many plant species $[49,50]$, including legumes $[13,36]$. The combination of a relatively high abundance of parrots 
compared to other frugivores in many ecosystems, their generalist trophic habits, and their extensive daily and seasonal movements make them pervasive dispersers of most of their food plants [49]. This includes stomatochory (i.e., seed dispersal transported externally with beaks and dropped after fruit consumption) [14,16,36,49,51], endozoochory (i.e., dispersal of viable seeds after gut passage) [52-55], and epizoochory (i.e., dispersal of seeds adhered to the body surface) [56]. These ecological roles, together with the understudied pollination and predation of invertebrate plant pests, can have a pervasive influence on ecosystem structure and functioning $[13,20,37,51,57]$. Therefore, the previously denied attention is essential to understand the ecological function of parrots in understudied systems in general and in Neotropical drylands poor in other avian frugivores in particular.

In this study, we examined the ecological interaction between the burrowing parrot (Cyanoliseus patagonus) and dominant algarrobo trees at the end of the fruiting period in the Monte Desert ecoregion. We recorded the abundance and foraging behaviour of parrots and quantified the handling, consumption, wasting, and dispersal of ripe and unripe pods. The viability of seeds from unripe and ripe pods wasted and transported by parrots was examined to determine whether their respective dispersal could be considered antagonistic or complementary mechanisms on plant demography. Finally, we conducted a snapshot sampling of faeces of wild mammals and livestock to determine the presence of algarrobo seeds dispersed by endozoochory.

\section{Material and Methods}

\subsection{Study Area}

The study was conducted in northwestern Argentina (provinces of Salta, Tucuman, and Catamarca), which is included in the northern range of the Monte Phytogeographic Province [58], comprising two ecoregions (High Monte and Low Monte) (https: / / ecoregions2 017.appspot.com, accessed on 24 April 2021) (Figure 1). In the High Monte (600-3500 m.a.s.l.), the climate is semi-arid to arid, with dry hot and cold rainy well-marked seasons $[58,59]$. Rainfall shows inter-annual variability but rarely exceeds $200 \mathrm{~mm}$, concentrated in summer. The surveyed area, mostly within the region of Valles Calchaquies, is occupied by native dry forests that have been converted to savanna- and steppe-like landscapes with variable levels of forest fragmentation for agriculture and soil erosion due to fire and free-ranging livestock $[60,61]$. More dense arboreal patches and riverine forests remain in valley bottoms and across the Calchaquí and Santa María rivers [61]. The flora is characterised by halophytic species of shrubby steppe and arboreal and shrub layers dominated by legumes (Fabaceae), especially algarrobos [58,62].
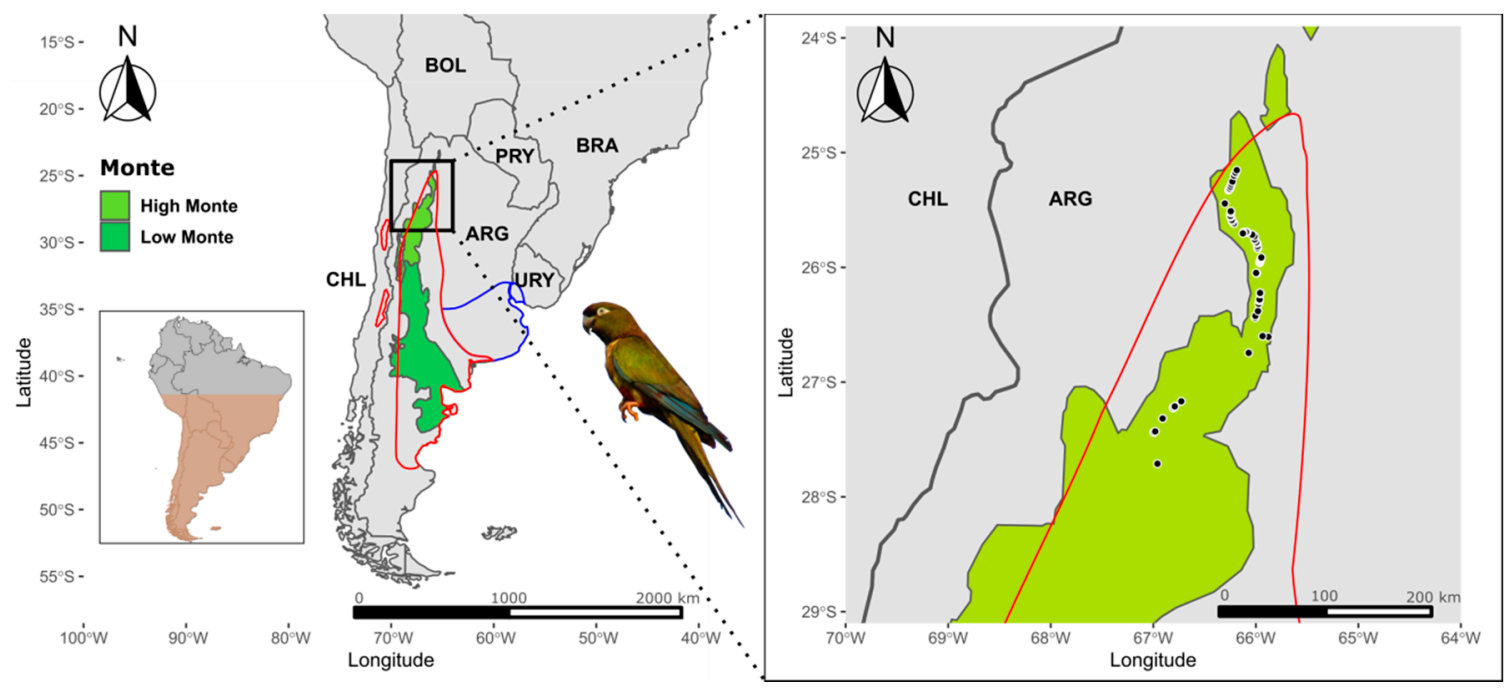

Figure 1. Map showing the distribution range of the burrowing parrot, including breeding (red line) and non-breeding (blue line) areas in southern South America (Argentina and Chile). The Monte Phytogeographic Province [58] comprising the High Monte and Low Monte Ecoregions (https: / / ecoregions2017.appspot.com, accessed on 24 April 2021) is shown. The study area is indicated by the black box, and locations where burrowing parrots were recorded are shown by black dots (right panel). 


\subsection{Study Species}

Prosopis is a primitive genus of shrubs and trees with currently disjointed natural distribution in Africa, Asia, and America. Prosopis alba and Prosopis nigra are medium-sized trees (4-16 m height) with widely overlapping distributions. Both species are present in the subtropical plains of north and central Argentina, Paraguay, and Uruguay and patches of semi-arid zones of Peru and Bolivia [24,25]. Genetically, they are close and poorly defined species [63]. Within the Algarobia section, to which both species belong, hybrids and introgression are relatively frequent [31,63-65]. The intraspecific morphological variations are usually high between localities [66]. Fruits are indehiscent, cylindrical, thick, and more or less compressed pods (length $\times$ width, $12-25 \times 1.1-2 \mathrm{~cm}$ and $10-16 \times 0.7-0.9 \mathrm{~cm}$ for P. alba and P. nigra, respectively). These may contain multiple seeds (generally $12-30$ and 8-27 for $P$. alba and P. nigra, respectively) and are wrapped in a sweet spongy mesocarp [24, $25,66,67]$. The mesocarp (hereafter, pulp) of both species is rich in sugars and relatively low in fat and protein. In the seeds, the proportion of proteins is high and much higher than that of fats $[67,68]$. Mature seeds of Prosopis have a hard and impermeable seed coat that prevents seed imbibition and germination (i.e., physical dormancy). The seeds of different Prosopis species are predated when they are still developing in the pods by birds and invertebrates, especially bruchid beetles (Chrysomelidae: Bruchinae), which may consume a large proportion of the seed crop [41,69]. Fallen fruits are preyed on and/or dispersed by endozoochory by greater rhea, wild mammals, reptiles, and livestock $[25,34,35,41,70]$. Rodents and invertebrates such as ants are seed predators and dispersers by stomatochory, followed by underground seed hoarding $[28,33,71]$.

The burrowing parrot inhabits the Monte Biogeographic Province, located in Argentina and Chile, southern South America (Figure 1). It includes two subspecies with an extensive distribution range across northwestern-central (C. p. andinus) and central-southern (C. p. patagonus) Argentina, respectively, and a presumable subspecies (C. p. conlara) hybrid between them [72]. The southern subspecies also inhabits the Patagonian steppe and the Espinal Biogeographic Provinces, including several ecoregions [73]. These subspecies are categorised as Least Concern, although their populations show variable degrees of threat, depending on the region, due to persecution and habitat loss and degradation [74]. A fourth subspecies (C. p. bloxami) inhabits a comparatively small distribution area in central Chile [72,75] and shows a small and declining population categorised as Endangered [74]. Burrowing parrots are colonial cliff nesters, nomadic and partially migratory, and gregarious foragers in variably-sized mobile flocks $[76,77]$. Depending on the subspecies, they exploit the fruits and seeds of different varieties of plants [72,75], whose crops are tracked through very long-distance flights from the breeding colonies and communal roosts [76]. They have also been recorded feeding on flowers, buds, and bark of native and exotic species [72,75] as well as on seeds of cultivated plants without causing remarkable impacts on crops [77]. No information is available on the role of this parrot as a mutualist or antagonist of their food plants except for observations of seed dispersal by stomatochory [36], the dispersal of the Atacama Desert shrub (Balsamocarpon brevifolium, Fabaceae) [32], and the lack of seeds dispersed by endozoochory over a limited snapshot sampling of faeces in southern Patagonia [53].

\subsection{Survey of Parrot Abundance and Foraging Observations}

During January 2020, coinciding with the fruiting period of algarrobos, we conducted surveys of burrowing parrots of the andinus subspecies in the northern Monte Biogeographical Province (hereafter Monte desert). We drove at low speeds $(20-40 \mathrm{~km} / \mathrm{h})$ along low-transited paved roads and unpaved tracks following the methodology used in previous studies $[13,57,78]$, totalling $529 \mathrm{~km}$ that were surveyed only once. The surveys were carried out by three persons, the driver and two observers, during the breeding season of the parrots. During the surveys, we counted the parrots observed and recorded their behaviour. We generally detected burrowing parrots visually, but when the survey track crossed dense woods generally associated with riparian forests with low visibility, we 
also detected parrots aurally. In these cases, we assigned the mean flock size of parrots detected visually to the aural records [78]. We also measured the perpendicular distance from the road to parrot flocks, using a laser rangefinder for estimating the density of this species through distance sampling modelling (see [79] for more methodological details and results). The obtained relative abundance (number of individuals $/ \mathrm{km}$ ) strongly correlated with density (number of individuals $/ \mathrm{km}^{2}$ ) estimates obtained through distance-sampling modelling in this and many other parrot species [78,79].

When foraging flocks were detected, we stopped the survey to observe with a telescope and binoculars their feeding behaviour including the food handling, the consumed part of each plant, the ripening state (ripe or unripe) of fruit pulp, and the maturation of seeds (soft or hard) of each exploited plant, identified to species or genera levels with field guides. We also recorded whether parrots dropped each food type beneath the canopy of food plants and confirmed what parrots were eating and wasting by searching for food remains on the ground beneath foraging sites, following the methodology previously detailed [14,57]. This information was also recorded for foraging flocks observed outside roadside surveys conducted to determine parrot abundance.

\subsection{Handling, Resource Consumption, and Wasting of Algarrobo Fruits}

After each observation of foraging on algarrobos, and when possible, depending on the location of food plants, we searched for pods handled and wasted by parrots on the ground beneath the foraging trees and the sites where the fruits were dispersed at a distance. At accessible sites, we collected a sample of these pods, which were clearly identified by the typical beak marks on them; no other parrot species inhabits the study area. Over a sample of the pods found to be handled by parrots $(n=363)$, we recorded whether they were entirely or partially consumed, the ripening state, and the part consumed by parrots. For unripe pods, which lacked pulp, we recorded the number of predated and intact seeds. In the case of ripe pods, we counted the number of seeds around which the pulp was consumed (i.e., consumed pulp) and the number of intact seeds remaining within or absent from each handled pod. We also estimated the proportion of the resources (pulp or seed) consumed over the total available in each handled pod.

\subsection{Seed Dispersal by Burrowing Parrots}

When parrots were located foraging, we recorded whether they flew and transported the fruits in their beaks from the fruiting trees to distant sites, thus dispersing the seeds by stomatochory (e.g., [14,16,57]). When the parrots ended feeding and left the area, we measured the exact dispersal distance (in metres) from the tree where the fruit was collected to where the fruit was released. This included other algarrobos, other tree and shrub species, and electric poles and wires, below which we confirmed, when possible, the presence of discarded entire fruits or fruit remains with seeds. When the foraging parrots moved far away with fruits in flight, we followed them using binoculars with a laser rangefinder (Leica Geovid $10 \times 42$ ) to measure the exact distance to which the parrots moved the fruits, either by losing and discarding the fruits in flight or from distant perches. In the particular situations when flying parrots carrying fruits from the food plant were lost from sight or when they were already carrying fruits in their beaks at first sighting, we followed the specifications described in previous studies to conservatively estimate minimum dispersal distances $[14,16,51,57]$.

We used MCMCglmm [80] to test differences in dispersal distances (log-transformed; cengaussian distribution) between the two algarrobo species (fixed effect). The model was run for 100,000 iterations, preceded by a burn-in of 10,000 iterations. Estimates of parameters were stored every 25th iteration to reduce autocorrelation. We tested the statistical support of the fixed effect by evaluating whether its posterior distribution (95\% credible interval) overlapped zero.

For a sample of flocks feeding on algarrobos, the rate of fruit movement leading to seed dispersal was estimated by recording the number of parrots that departed simultaneously 
in flight with pods in their beaks over the total number of parrots that formed each flock [16,51,57]. Given the large size of several of the flocks, which often fed on several nearby trees, the observations were coordinated between three observers, each of whom focussed on different fractions of the flocks to better count parrots moving pods.

\subsection{Seed Viability}

Samples of unripe and ripe pods of each algarrobo species wasted by parrots were collected and dried with a forced-air heater to simulate the drying conditions in the hot austral summer in the Monte Desert. Once the pods were completely dry, they were stored at room temperature until arrival at the laboratory, where the seeds from each pod were extracted and counted. We determined whether each seed was colonised by bruchid beetles by recording larvae, pupae, or the characteristic adult exit hole in the endocarp [69]. Non-parasitised seeds were tested for viability using the tetrazolium test [81]. After cutting with a scalpel, seeds were incubated in a $1 \%$ solution of 2,3,5-triphenyl tetrazolium chloride for $48 \mathrm{~h}$. The tetrazolium reacted with respiring radicles to produce a red stain when the seed was viable, while non-stained white radicles indicated non-viable seeds [81]. This test was conducted to assess whether seeds from unripe pods wasted and dispersed by parrots retained viability compared to seeds from ripe pods, rather than to precisely determine germination potential and rate, which would require germination experiments [55].

\subsection{Algarrobo Seeds Excreted by Livestock and Wild Mammals}

In the area surveyed for parrot presence and abundance, we conducted a random search for faeces of free-ranging livestock (cows and equids) and wild large-bodied mammals that could act as potential dispersers of algarrobo seeds [41]. A random sample of fresh faeces was shredded in situ to determine the presence of seeds. We opportunistically recorded the presence of invertebrates dispersing seeds wasted by parrots as well as those present in mammal faeces.

\section{Results}

\subsection{Parrot Abundance and Foraging}

During the surveys, we recorded 98 flocks of burrowing parrots totalling $1559 \mathrm{ob-}$ served individuals, which represented a relative abundance of 2.95 parrots per $\mathrm{km}$ surveyed. Relative abundance reached 3.61 parrots $/ \mathrm{km}$ when adding the estimated number of parrots that were only heard. The estimated density obtained through distance sampling modelling was 18.17 individuals $/ \mathrm{km}^{2}$. All observations were recorded in the High Monte ecoregion (Figure 1).

We located 40 flocks foraging on six plant species (Table 1). The flocks for which we were able to determine the number of individuals were composed of 1 to 160 parrots (mean $\pm \mathrm{SD}=25.2 \pm 8.1, n=27$ ). Most foraging records corresponded not only to the consumption of seeds and pulp of algarrobo pods and other legume species (Fabaceae) but also to flowers of a hemiparasite mistletoe (Ligaria cuneifolia, Lorenthaceae) and fleshy bark of branches of a columnar cactus (Trichonocereus atacamensis, Cactaceae) (Table 1). All foraging observations confirmed food wasting of each type of plant part consumed, including partially consumed and entire unripe and ripe fruits or their components (seeds and pulp) as well as flowers and branch bark (Table 1).

\subsection{Pod Handling and Consumption}

Overall, we collected 363 algarrobo pods handled and partially or entirely consumed, wasted, or dispersed by burrowing parrots (Figure 2A,B), corresponding to P. alba ( $n=113$ unripe pods from four trees and $n=164$ ripe pods from three trees) and P. nigra ( $n=33$ unripe pods from nine trees and $n=53$ ripe pods from nine trees); some of the sampled unripe and ripe pods corresponded to the same trees. When feeding on unripe pods, parrots focussed on the consumption of seeds (soft) in all cases while discarding other fruit parts of both species (Figure 2C,E). When feeding on ripe pods, they only consumed 
the pulp but never the seeds (hard) or other parts in both species (Figure 2D,E).

Table 1. Abundance, food plant species, feeding behaviour, and seed dispersal of burrowing parrots in the Monte Desert, Argentina.

\begin{tabular}{|c|c|c|c|c|c|c|c|c|c|c|}
\hline \multirow[b]{2}{*}{ Family Plant Species } & \multirow[b]{2}{*}{$n$ Flocks (\%) } & \multirow[b]{2}{*}{$n$ Parrots (\%) } & \multicolumn{3}{|c|}{ Plant Part Consumed ${ }^{a}$} & \multicolumn{2}{|c|}{ Fruit Part Consumed $^{\mathrm{c}}$} & \multicolumn{3}{|c|}{ Seed Dispersal (Pod) } \\
\hline & & & Fruit (\%) & Flower (\%) & Other $b_{(\%)}$ & Seed $(\%)$ & Pulp (\%) & Unripe (\%) ${ }^{d}$ & Ripe (\%) ${ }^{\mathrm{d}}$ & Total $(\%)^{d}$ \\
\hline \multicolumn{11}{|l|}{ Fabaceae } \\
\hline Geoffroea spinosa & $1(3.7)$ & $5(0.7)$ & $1(2.6)$ & & & & $1(4.0)$ & & $1(100)$ & $1(100)$ \\
\hline Parkinsonia praecox & $6(22.2)$ & $30(4.4)$ & $6(15.8)$ & & & $6(24.0)$ & & $0(0.0)$ & $0(0.0)$ & $0(0.0)$ \\
\hline Prosopis alba & $10(37.0)$ & $363(53.4)$ & $14(36.8)$ & & & $5(20.0)$ & $13(52.0)$ & $1(20.0)$ & $6(46.2)$ & $7(38.9)$ \\
\hline Prosopis nigra & $7(25.9)$ & $173(25.4)$ & $16(42.1)$ & & & $14(56.0)$ & $11(44.0)$ & $6(42.9)$ & $3(27.3)$ & $9(36.0)$ \\
\hline Prosopis sp. & $1(3.7)$ & $22(3.2)$ & $1(2.6)$ & & & & & & & \\
\hline \multicolumn{11}{|l|}{ Loranthaceae } \\
\hline Ligaria cuneifolia & $1(3.7)$ & $75(11.0)$ & & $1(100)$ & & & & & & \\
\hline \multicolumn{11}{|l|}{ Cactaceae } \\
\hline Trichonocereus atacamensis & $1(3.7)$ & $12(1.8)$ & & & $1(100)$ & & & & & \\
\hline Total & 27 & 680 & 38 & 1 & 1 & 25 & 25 & 7 & 10 & 17 \\
\hline
\end{tabular}

a Refers to flocks, including those for which the number of parrots was not determined accurately. Flocks often fed on several nearby trees, including Prosopis trees of both species. ${ }^{b}$ Fleshy bark of branches. ${ }^{c}$ Consumed seeds correspond to unripe legume pods, while pulp was exploited from ripe pods. Both unripe and ripe pods were simultaneously available in several Prosopis trees. Therefore, a single flock could be computed twice when parrots consumed both unripe and ripe pods. ${ }^{d}$ Percentage calculated of the total number of foraging observations on seeds (unripe pods) from P. alba $(n=5)$ and P. nigra $(n=14)$ and pulp (ripe pods) from P. alba $(n=13)$ and $P$. nigra $(n=11)$.
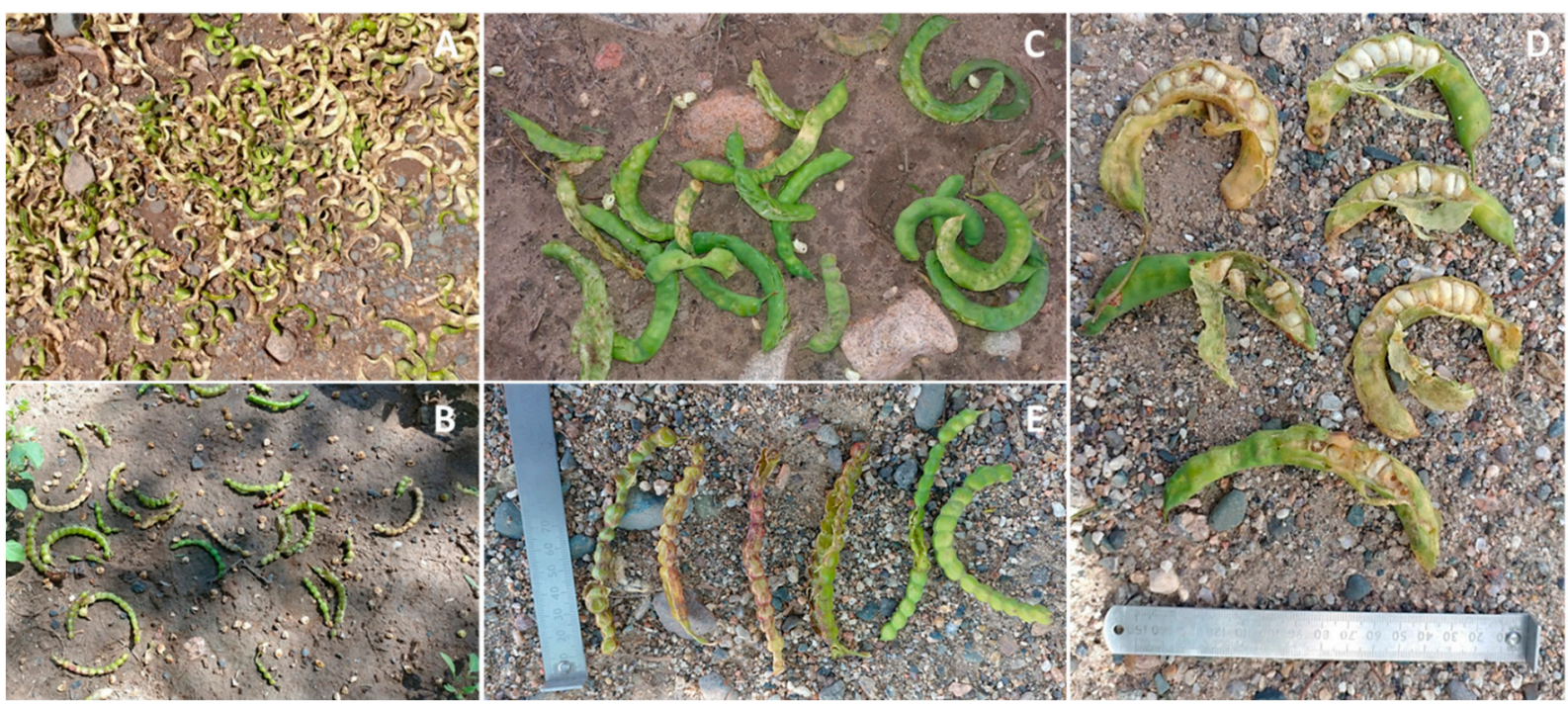

Figure 2. (A) Ripe and unripe pods of Prospis alba (A) and Prosopis nigra (B) accumulated beneath fruiting trees after feeding bouts by burrowing parrots. Details of wasted and partially consumed unripe (C) and ripe (D) pods of $P$. alba and of $P$. nigra (E). Pictures: G. Blanco.

Among the unripe pods handled, most were partially consumed, while a lesser proportion was wasted entirely or partially consumed, and these figures differed between algarrobo species (Fisher's exact test, $p<0.0001$; Figure 3A). Most ripe pods of both species were also partially consumed, and their handling also differed between species (Fisher's exact test, $p<0.001$; Figure 3B).

Given the differences in the handling and consumption of pods depending on ripening state and species and due to species-specific differences in pod size-related availability of food for parrots (seeds and pulp) and the number of seeds (see Study Species section), we analysed partially and completely consumed or wasted entire pods separately for each species. The mean number of seeds predated per pod (unripe pods), wasted inside pods (unripe and ripe pods), or missing (ripe pods) are shown in Table 2 for each species. Overall, parrots consumed a similar number of seeds (6-7) from unripe pods of both species (Mann-Whitney U test, $z=1.93, p=0.054, n_{\text {alba }}=76, n_{\text {nigra }}=145$, Table 2 ). The number of seeds remaining inside wasted pods after handling (pods partially or completely consumed) was higher in P. alba (about 11-14) than P. nigra (about 4-8), both for unripe and ripe pods $\left(z=7.17, n_{\text {alba }}=76, n_{\text {nigra }}=145\right.$ and $z=4.60, n_{\text {alba }}=32, n_{\text {nigra }}=38$, respectively, 
both $p<0.0001$, Table 2). The number of seeds missing from ripe pods (about 2) was much lower than those remaining in them after handling by parrots (Table 2) but was similar between species $\left(z=1.72, p=0.08, n_{\text {alba }}=32, n_{\text {nigra }}=38\right.$, Table 2$)$. Regardless of the fate of seeds, their total numbers were similar between pods partially or completely consumed and those wasted entirely in within-species comparisons (see Table 2).
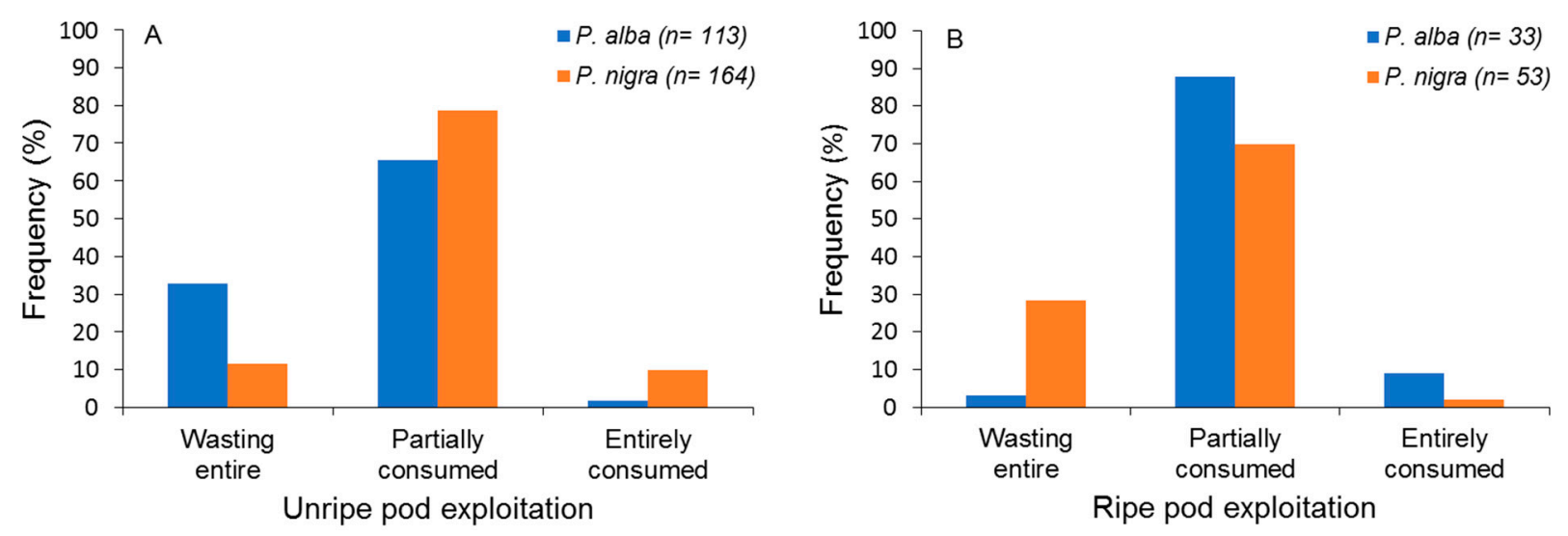

Figure 3. Frequency of each type of handling and consumption of unripe (A) and ripe (B) pods of two algarrobo species (Prosopis alba and Prosopis nigra) by burrowing parrots.

Table 2. Number (mean \pm SD) and range (in parentheses) of seeds predated, wasted, and missing per pod according to the ripening state and consumption (partial and total) and wasting (entire) of pods of two algarrobo species handled by burrowing parrots. Missing seeds refer to hard seeds from ripe pods that did not remain inside the pod once discarded by parrots (i.e., assumed to be wasted outside the pod or dispersed by epizoochory). Consumed pulp corresponds to the number of seeds around which the pulp was consumed. $n_{\mathrm{p}}, n_{\mathrm{s}}$ indicate sample sizes for pods and seeds, respectively.

\begin{tabular}{|c|c|c|c|c|c|c|c|c|}
\hline & \multicolumn{6}{|c|}{ Pods Partially or Completely Consumed } & \multicolumn{2}{|c|}{ Pods Wasted Entirely } \\
\hline & Predated Seeds & Wasted Seeds Inside Pods & Missing Seeds & Total & Consumed Pulp & $n_{\mathrm{p}}, n_{\mathrm{s}}$ & $\begin{array}{c}\text { Wasted } \\
\text { Seeds }\end{array}$ & $n_{\mathrm{p}}, n_{\mathrm{s}}$ \\
\hline Unripe pods & & & & & & & & \\
\hline Prosopis alba & $\begin{array}{c}7.3 \pm 4.7 \\
(1-22)\end{array}$ & $\begin{array}{c}11.1 \pm 7.7 \\
(0-30)\end{array}$ & - & $\begin{array}{c}18.5 \pm 5.6 \\
(8-31)\end{array}$ & - & 76,1405 & $\begin{array}{c}20.2 \pm 7.1 \\
(5-32)\end{array}$ & 37,748 \\
\hline Prosopis nigra & $\begin{array}{c}5.9 \pm 3.5 \\
(1-15)\end{array}$ & $\begin{array}{c}4.1 \pm 3.4 \\
(0-17)\end{array}$ & - & $\begin{array}{c}10.0 \pm 3.4 \\
(2-20)\end{array}$ & - & 145,1446 & $\begin{array}{c}9.8 \pm 4.5 \\
(3-17)\end{array}$ & 19,187 \\
\hline \multicolumn{9}{|l|}{ Ripe pods } \\
\hline Prosopis alba & - & $\begin{array}{c}14.4 \pm 5.6 \\
(4-24)\end{array}$ & $\begin{array}{c}1.7 \pm 3.7 \\
(0-15)\end{array}$ & $\begin{array}{c}16.2 \pm 4.3 \\
(9-28)\end{array}$ & $\begin{array}{c}8.7 \pm 4.8 \\
(1-19)\end{array}$ & 32,517 & 10 & 1,10 \\
\hline Prosopis nigra & - & $\begin{array}{c}8.2 \pm 4.1 \\
(1-16)\end{array}$ & $\begin{array}{c}2.2 \pm 2.8 \\
(0-9)\end{array}$ & $\begin{array}{c}10.3 \pm 3.3 \\
(4-16)\end{array}$ & $\begin{array}{c}4.4 \pm 3.0 \\
(1-14)\end{array}$ & 38,393 & $\begin{array}{c}11.1 \pm 4.8 \\
(3-18)\end{array}$ & 15,167 \\
\hline
\end{tabular}

Considering pods partially or completely consumed, the exploitation of seeds reached an average of $43.7 \%$ (SD $=28.5 \%$, range $=3.2-100 \%)$ of the available ones in each unripe P. alba pod ( $n=558$ seeds from 76 pods) and $60.1 \%$ (SD $=28.28 \%$, range $=5.6-100 \%$ ) in P. nigra ( $n=856$ seeds from 145 pods). Regarding ripe pods, parrots consumed $54.5 \%$ $(\mathrm{SD}=28.6 \%$, range $=5.3-100 \%)$ of the available pulp in P. alba pods $(n=277$ seeds from 32 pods $)$ and $44.4 \%(\mathrm{SD}=26.6 \%$, range $=6.3-100 \%)$ in $P$. nigra pods $(n=169$ seeds from 38 pods).

\subsection{Rate and Distance of Seed Dispersal}

In addition to seed dispersal beneath food plants due to food wasting (Figure 2A-C and Figure $4 \mathrm{~A}$ ), we recorded primary pod dispersal by stomatochory at a distance from the mother plant for both algarrobo species (Figure 4B,C) and for spherical fruits with a single seed each in the case of Geoffroea spinosa (Fabaceae) (Table 1). A proportion of the flocks feeding on algarrobos moved pods away, thus dispersing soft and hard seeds of both species (Table 1). 

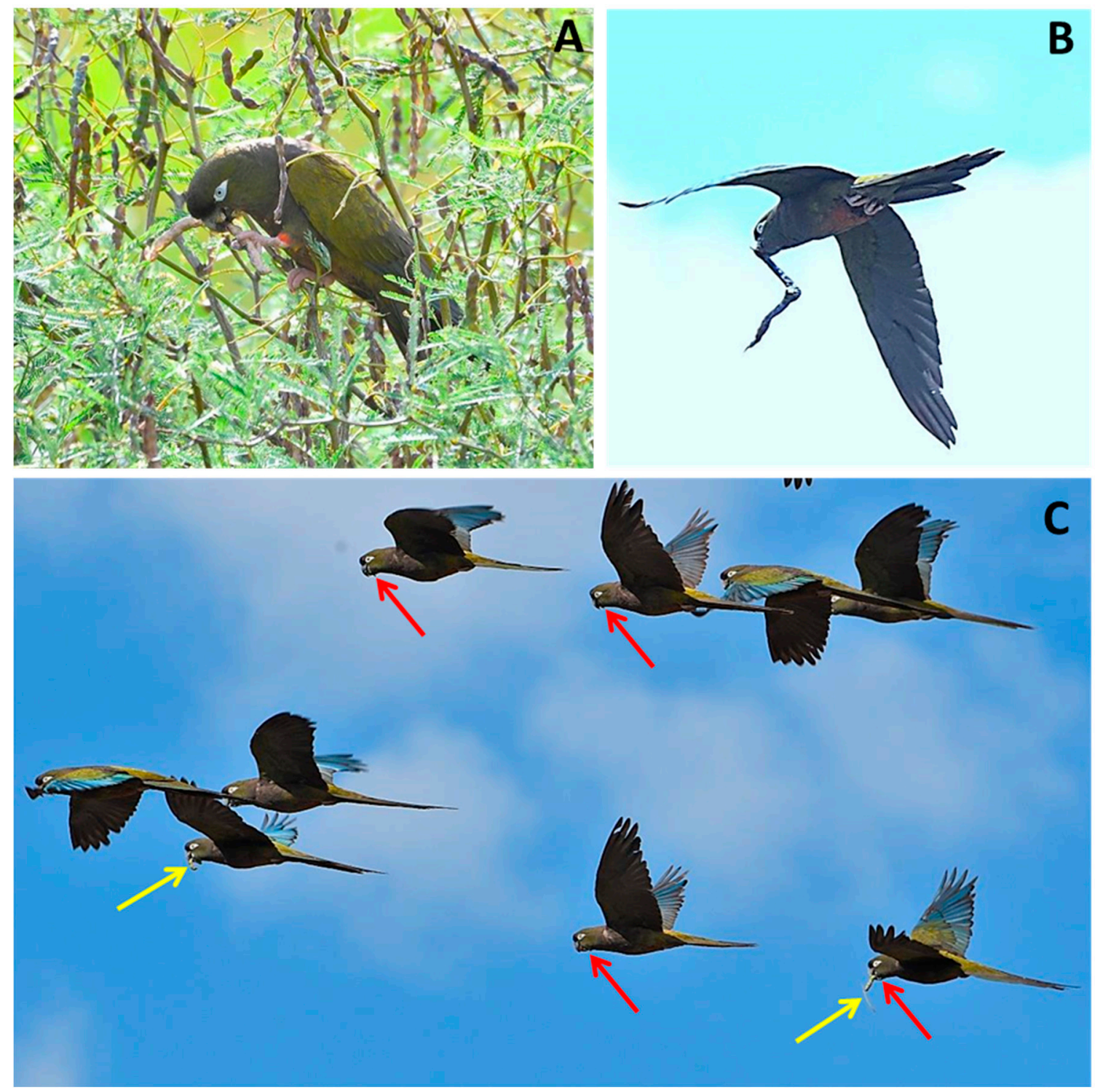

Figure 4. Burrowing parrots feeding on ripe pods of Prospis nigra (A)and dispersing ripe pods of Prospis alba (B) and ripe pods of Prosopis nigra (C). Yellow arrows indicate pods transported in the beak (stomatochory), and red arrows indicate seeds dispersed adhered to throat feathers (epizoochory). Pictures: J.L. Tella.

The proportion of parrots departing with pods or without pods in their beaks was estimated for 20 flocks composed of $36.1 \pm 44.5$ parrots (range $=2-160$ ) feeding on P. alba ( $n=12$ trees or groups of trees), P. nigra $(n=11)$, and G. spinosa $(n=1)$; note that some particular flocks were feeding on nearby algarrobo trees of both species. In about half of these flocks $(55.0 \%, n=20)$, at least one parrot departed with pods in its beak. The mean proportion of dispersing parrot flocks moving pods was $13.1 \%(\mathrm{SD}=6.2 \%$, range $=6.7-23.1)$ for $P$. alba ( $n=7$ flocks), $33.9 \%$ (SD $=44.8 \%$, range $=4.5-100)$ for $P$. nigra $(n=4$ flocks $)$, and $20.0 \%$ for $G$. spinosa ( $n=1$ flock of five parrots). In the remaining flocks, parrots departed without fruits in their beaks.

Minimum dispersal distances did not differ between $P$. alba $(54.8 \pm 93.8 \mathrm{~m}$, median $=16$, range $=10-530, n=65)$ and $P$. nigra $(54.0 \pm 62.6 \mathrm{~m}$, median $=30$, range $=3-180, n=71)$ (Mann-Whitney $\mathrm{U}$ test, $\mathrm{z}=1.38, p=0.17$ ). Exact dispersal distances also did not differ between P. alba $(73.4 \pm 28.4 \mathrm{~m}$, median $=76$, range $=23-160, n=15)$ and P. nigra $(79.2 \pm 66.4 \mathrm{~m}$, median $=92$, range $=5-150, n=6)(\mathrm{z}=0.03, p=0.97)$ (Figure 5A). Estimated dispersal distances did not differ between the two algarrobo species (posterior mean: 0.26, 95\% credible interval: $-0.10-0.68)$, although they were larger for P. nigra $(417.8 \mathrm{~m}, 95 \%$ credible 
interval: $187.50-972.75)$ compared to $P$. alba ( $237.7 \mathrm{~m}, 95 \%$ credible interval: $138.0-485.3)$ (Figure 5B). The single dispersal distance recorded for G. spinosa was $93 \mathrm{~m}$.
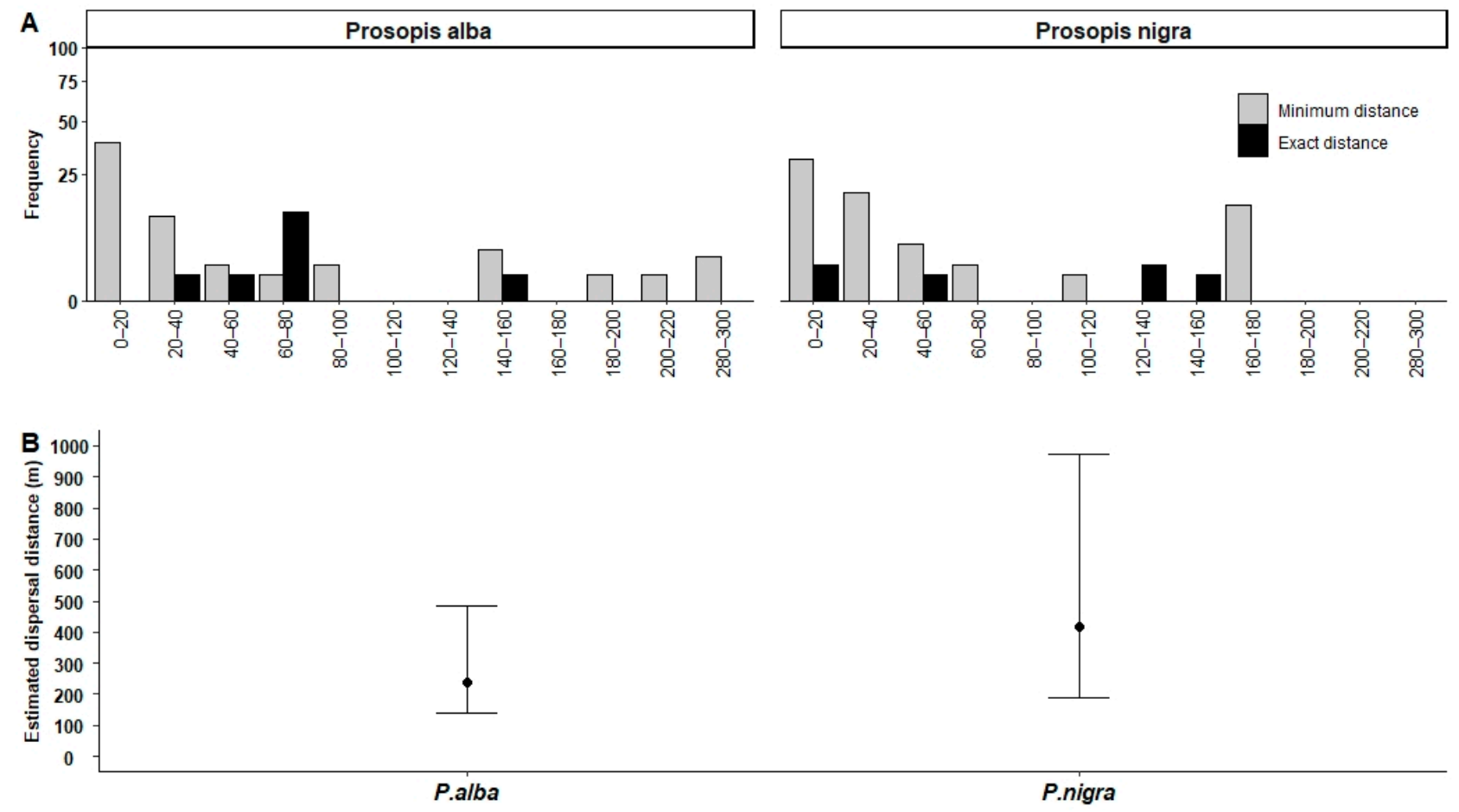

Figure 5. Dispersal distances (in $\mathrm{m}$ ) for algarrobo pods dispersed by burrowing parrots. (A) Minimum (grey bars) and exact (black bars) distances recorded for each species shown in intervals of $20 \mathrm{~m}$. Intervals without data are absent from the graph. (B) Estimates of the mean dispersal distance for P. alba and P. nigra, obtained from the MCMCglmm function. The highest posterior density (HPD) interval at $95 \%$ fixed probability is shown for both species.

During foraging observations on the ripe pods of both algarrobo species, we ascertained the presence of seeds adhering to the beak and the face and throat feathers of parrots. After examining pictures of flying individuals dispersing pods by stomatochory, we confirmed seed dispersal by epizoochory as a consequence of feeding on the sticky pulp of ripe pods (Figure 4C). However, we were unable to estimate the frequency of this type of dispersal or the number of seeds dispersed.

\subsection{Viability of Seeds Wasted and Dispersed by Parrots}

Most seeds from unripe and ripe wasted and dispersed pods of both algarrobo species were predated by bruchid beetles (Table 3 ). Among non-parasitised seeds, about half were viable and the other half unviable according to the tetrazolium test (Table 3). There was no significant difference in the proportion of viable seeds between unripe and ripe pods of each species wasted by parrots (generalised linear model, binomial error distribution, logit link function; algarrobo species, $\chi^{2}=0.36, p=0.55$; ripening state, $\chi^{2}=0.08, p=0.78$; interaction, $\chi^{2}=0.30, p=0.58$, Table 3). 
Table 3. Frequency (mean $\% \pm \mathrm{SD}$ ) of algarrobo seeds predated by bruchid beetles per pod handled by burrowing parrots, depending on their ripening state. Non-parasitised seeds were tested for viability using the tetrazolium test.

\begin{tabular}{lcccc}
\hline & & \multicolumn{2}{c}{ Seeds } \\
\hline Species & Sample Size & Parasitised & \multicolumn{2}{c}{ Non-Parasitised } \\
\hline Pod State & Pods/Seeds & & Unviable & Viable \\
\hline Prosopis alba & & & & \\
Unripe & $20 / 320$ & $92.8 \pm 7.3$ & $4.2 \pm 4.1$ & $3.0 \pm 5.0$ \\
Ripe & $31 / 603$ & $89.1 \pm 8.9$ & $6.4 \pm 7.3$ & $4.5 \pm 4.6$ \\
Prosopis nigra & & & & \\
Unripe & $5 / 53$ & $78.7 \pm 20.3$ & $12.4 \pm 15.7$ & $8.9 \pm 8.3$ \\
Ripe & $8 / 82$ & $86.5 \pm 10.0$ & $6.2 \pm 5.2$ & $7.2 \pm 6.4$ \\
\hline
\end{tabular}

\subsection{Seeds in Mammal Faeces and Secondary Dispersal}

A small proportion of livestock faeces contained algarrobo seeds, including faeces from cattle (Bos taurus; $2.4 \%, n=85$ ) and equids (Equus spp; $5.0 \%, n=101$ ). Among wild animals, we found no seeds in the faeces of the guanaco (Lama guanicoe; $0.0 \%, n=86$ ), while half of the small number of faeces of the South American grey fox (Lycalopex griseus) contained seeds $(50.0 \%, n=6)$.

Seeds from algarrobo pods wasted by parrots were observed being secondarily dispersed by columns of unidentified ants, which we did not quantify. Moreover, ants were observed dispersing algarrobo seeds from equid faeces ( $n=1$ of 5 faeces with seeds, $20.0 \%$ ), while coprophagus beetles (Scarabaeidae) were observed dispersing seeds within dung balls from cattle ( $n=1$ of 2 faeces with seeds, $50.0 \%$ ) and fox faeces $(n=1$ of 3 faeces with seeds, $33.3 \%$ ).

\section{Discussion}

Understanding the structure and functioning of increasingly human-altered drylands requires detailed knowledge about plant-animal interactions. Special attention has been given to the nature and strength of the interactions involving keystone and unique species in food and mutualistic webs before they become extinct or functionally threatened [9]. Here, we highlight the unrecognised role played by a bird species, the burrowing parrot, as the main disperser of the dominant trees of the Monte Desert. Our results show a very high abundance of burrowing parrots in the northern Monte Desert compared to other Neotropical parrot species $[13,57,78]$. In fact, the relative abundance and density of burrowing parrots in the Monte Desert are higher than those of the same species in other ecoregions [82] and are among the five highest obtained from 575 abundance surveys of 137 parrot species across the world [79]. No other large- or medium-sized frugivorous birds with the potential to act as seed dispersers were recorded during these surveys. In fact, the Monte Desert is poor in this type of species [83], and only the greater rhea has been suggested as a disperser of legume seeds [34,35]. Other bird species exploiting legume pods have been assumed to be exclusive pre-dispersal seed predators, including the burrowing parrot, the other parrot species partially inhabiting this biome at southern latitudes (i.e., the monk parakeet Myiopssita monachus), and some passerine birds [28,69]. Contrary to previous assertions not supported by sound, specific research on bird-legume interactions, we found evidence that burrowing parrots were frequent primary, long-distance dispersers of algarrobo seeds.

Burrowing parrots only predated on soft seeds from unripe pods, while they exclusively fed upon the pulp wrapping hard seeds from ripe pods of both algarrobo species. This food selectivity depending on the fruit ripening state and seed hardening has been cited for other parrot-legume interactions $[13,84-86]$ and could be related to the nutrients provided in each case $[87,88]$. Unripe pods provide soft seeds rich in proteins and water, while ripe pods provide abundant sweet pulp rich in carbohydrates $[67,68]$. In addition 
to these changes in nutritional composition, dry and hard seeds may be less attractive to parrots when abundant pulp is available in ripe pods. Alternatively, burrowing parrots can have difficulties cracking or digesting these hard seeds, even though the strong beaks of parrots enhance the consumption of very hard items [16,49]. The wide phenological range of algarrobo fruiting allows parrots to exploit these nutrients in different or the same trees in each feeding bout. These resources can be selected or exploited depending on the abundance in each tree, spatial area, or period and based on the contrasting physiological needs of individuals for reproduction (nestling provisioning) or maintenance $[87,88]$. Whatever the case, our results indicate a close dependence of burrowing parrots on fruits of the dominant trees of the northern Monte Desert. Other plant species were exploited much less frequently due to their lower abundance and biomass and likely due to different phenological stages and resources provided, a determination that requires assessment through year-round studies.

The typical wasteful feeding of parrots implies that most handled unripe and ripe pods were partially consumed or discarded entirely. This behaviour has been documented for all parrot species examined and for those feeding on legumes of many species [50]. Wasting implies that burrowing parrots discarded beneath the mother plant or at a distance after dispersal all hard seeds from the ripe pods handled and partially exploited for pulp as well as a proportion of soft seeds from unripe pods. The relatively large size of pods including many seeds (ripe and unripe pods) and abundant pulp (ripe pods) could also contribute to their partial consumption and wasting. This is supported by the similar quantity of food extracted from pods of both species, despite their different size and number of seeds. Moreover, wasting entails a higher number of soft and hard seeds remaining inside after handling the larger P. alba pods as compared to P. nigra pods. Thus, each partially consumed pod wasted beneath the tree or moved away implies the dispersal of about half of the seeds available for parrots, with average ranges between 4 and 14 seeds per pod depending on species and ripening state and a maximum of up to 30 seeds per pod. These figures were slightly higher for pods wasted entirely. Therefore, the wasting beneath the plant or transport of pods at a distance invariably implies the dispersal of multiple seeds in each event.

Stomatochory has been previously documented for many parrot-plant interactions $[14,16,20,36,49,51]$, including P. alba, P. kuntzei, and other legumes moved by four parrot species at minimal distances of up to $400 \mathrm{~m}$ in the Bolivian inter-Andean dry forest [13]. The much-longer-than-wider shape of legume pods allows parrots to move these large, multi-seeded fruits in flight, thus relaxing the physical limitations imposed by spherical fruits for transport in the beak, depending on parrot species-specific size [49]. We estimated that in about half of the flocks, at least one parrot departed in flight from the fruiting trees with pods in its beak, with 10-34\% of the flock individuals moving pods. These figures were similar or higher than those previously estimated in other parrot-plant interactions (ranging from 4.8 to $29.6 \%$ ) [51,57], except for the highest seed dispersal rate of bush-layer Attalea palms [16]. The exact dispersal distances recorded ranged from 5 to 160 $\mathrm{m}$, while the mean dispersal distances estimated when controlling for the right-censored distribution of our data estimated $238 \mathrm{~m}$ for $P$. alba and $418 \mathrm{~m}$ for $P$. nigra. These distances were well above $100 \mathrm{~m}$, a distance threshold often used to define long-distance seed dispersal (see [19] and references there). Therefore, similarly to other parrot species [14,16,49], burrowing parrots may act as short- and long-distance seed vectors by stomatochory. In addition, we found that two hard seeds were missing, on average, from ripe pods of both algarrobo species after handling by parrots. This suggests that a small number of hard seeds were wasted outside pods or were primarily dispersed by epizoochory documented for the first time in this species. This dispersal mechanism has been little explored in parrots, but a recent review has shown that it is more widespread than previously thought [56]. Through epizoochory, parrots could presumably disperse seeds at a much longer distance than by stomatochory, as burrowing parrots often conduct non-stop flights of tens of kilometres [76]. Both long-distance dispersal mechanisms by parrots can contribute to 
explaining the phylogeography and population genetics of the genus Prosopis in South America, which was previously hypothesised to be due to bird seed dispersal, although the avian disperser species were unknown [31]. In fact, many parrot species disperse legumes in other Neotropical dry biomes [13,36,50]. In support of this hypothesis, the radiation centre and distribution range of the section Algarobia [31,89] largely overlap with that of the nomadic and partially migratory burrowing parrot [72], coinciding in time with the spreading of arid areas in the Americas after the Andean uplift [72,89-91]. Further research is warranted, including the assessment of epizoochory and potential endozoochory, to determine the dispersal role of burrowing parrots in the phylogeography and population genetics of their food plants.

As in other studies [41,69], a high proportion of algarrobo seeds was predated by bruchid beetles. Among non-predated seeds, no significant difference was found in the proportion of viable seeds from unripe and ripe pods after being handled by parrots. The transport of unripe pods could thus contribute to the dispersal of viable seeds. This agrees with previous studies showing that seeds from the unripe fruits of several plant species may retain viability and germinate after external dispersal $[45,48]$. This mechanism may add spatiotemporal heterogeneity to the process of seed dispersal as a potential complementary plant adaptation to increase the likelihood of seedling establishment, depending on the feeding behaviour and food selectivity of dispersers. In fact, the predation of a proportion of soft seeds from unripe pods was invariably accompanied by the wasting or dispersal of a similar number of seeds. In agreement with other parrot-plant interactions, multiple-seeded algarrobo pods associated with burrowing parrot stomatochory could be an adaptive interaction with eco-evolutionary consequences for both partners $[13,16,37,51,57]$. Specifically, large pods providing different food resources may satiate parrots predating soft seeds, thus also promoting their role as dispersers [51,57]. In this form, plants can ensure the movement of a proportion of viable seeds regardless of fruit maturation state [48]. Determining whether this dual parrot-legume interaction evolved in the context of antagonism-mutualism continuums $[16,37]$ and whether it has implications in the evolution of fruit traits would require future studies. Further research is also needed to determine whether seed hardening and desiccation outside the mother plant may influence the dormancy and germinability of soft seeds.

Besides acting as frequent primary dispersers of algarrobo seeds, burrowing parrots wasting pods provided food for secondary dispersers like wild and domestic vertebrates and invertebrates (mainly ants). Even when livestock and wild ungulates can feed on accessible fruits directly from trees, our snapshot sampling of faeces suggests a low frequency of seed dispersal by livestock and guanacos but a higher frequency in a very small sample of grey fox scats. When algarrobo woods consist mainly of an arboreal layer, these dispersers could be limited to the consumption of pods fallen passively when ripe at the very end of the fruiting period. Therefore, wasteful feeding of parrots may increase the food availability for secondary seed dispersers, thus also widening the dispersal period and the range of potential dispersers $[49,50]$. Seed scarification and physical dormancy-breaks due to consumer gut passage can enhance germination speed after excretion in controlled but artificial greenhouse conditions. However, rather than being an adaptive advantage, seed excretion within large faeces (especially from large livestock) can be an ecological trap wherein seeds can be "forced" to quick germination, rarely developing to viable seedling establishment $[29,40,92,93]$. This can be enhanced by dormancy breaking coupled with faecal moisture favouring immediate germination at unsuitable times (e.g., before the rainy season) and conditions including high seed density, increasing seedling competition, nitrogen concentration, pathogen loads, and predator attraction, thus overall constituting an unfavourable microhabitat for seedling establishment $[29,93]$. The higher and long-lasting moisture from large faeces of livestock, especially cattle, as compared to the much smaller and drier faeces of native vertebrates, could drive differences in germinability and seedling establishment $[41,92,93]$. These factors could also exert an influence on the action of secondary dispersers like scatter-hoarding rodents and ants $[29,94]$ and dung beetles recorded 
dispersing seeds from livestock and fox faeces during our limited snapshot sampling. On the contrary, the external dispersal by parrots does not imply any direct influence on seed physical dormancy besides a potential de-inhibition effect [95] by defleshing a small proportion of hard seeds. Seeds wasted by parrots are frequently deposited where they could be secondarily dispersed, while seeds moved away can be dispersed at microhabitats and seed banks where the scarification and subsequent germination takes place under natural environmental conditions [96].

\section{Conclusions}

The high abundance of the burrowing parrot in the Monte Desert suggests that a high number of multiple-seeded ripe and unripe pods are moved daily during their respective periods of availability. The high dispersal rates recorded associated with the typical daily routines of foraging flocks from breeding colonies and communal roosts can clearly contribute to this function. These routines consist of 1-4 daily flights of more than $60 \mathrm{~km}$ with multiple foraging stops across their roundtrip flights between the breeding colony and foraging areas and nomadic and partially migratory movements over extended home ranges of thousands of square kilometres [73,76,77]. Wasting and dispersal events occurred in most foraging bouts, both beneath and away from each mother plant. Therefore, the overall strength of seed dispersal can be amplified through successive foraging events across different extensive areas exploited daily, seasonally, and inter-annually $[73,76,77]$. This additive-like process, encompassing multiple seed dispersal events daily by a proportion of individuals, can represent the movement of huge amounts of seeds across large areas exploited sequentially. Further research is needed to quantify the number of seeds and accumulated dispersal distances attributed to the burrowing parrot and to evaluate its role as a functionally unique species (sensu [9]) in the structure and functioning of algarrobo woods in the Monte Desert.

Author Contributions: Conceptualization, G.B., P.R.-V., M.C., F.H. and J.L.T.; methodology, G.B., P.R.-V., M.C., D.C., C.B., F.H. and J.L.T.; software, P.R.-V. and M.C.; validation, G.B., P.R.-V., M.C., F.H. and J.L.T.; formal analysis, G.B., P.R.-V., M.C. and J.L.T. investigation, G.B., P.R.-V., M.C., D.C., C.B., F.H. and J.L.T.; resources, J.L.T.; data curation, G.B., P.R.-V., M.C., D.C., C.B., F.H. and J.L.T.; writing-original draft preparation, G.B.; writing-review and editing, G.B., P.R.-V., M.C., D.C., C.B., F.H. and J.L.T.; visualization, G.B., P.R.-V., M.C., F.H. and J.L.T.; supervision, G.B., M.C., F.H. and J.L.T.; project administration, M.C., J.L.T.; funding acquisition, J.L.T. All authors have read and agreed to the published version of the manuscript.

Funding: This research was funded by the Loro Parque Fundación (grant reference: PP-146-2018-1).

Institutional Review Board Statement: Not applicable. This work did not require approval by our respective Ethical Committees because it did not involve invasive methods or experimental work with live animals.

Informed Consent Statement: Not applicable.

Data Availability Statement: Most data are provided in the text in the form of percentages and sample sizes. Additional detailed data sets can be requested from the corresponding author.

Acknowledgments: We thank two anonymous reviewers, and I. Afán (LAST-EBD) for helping in the design of road surveys using satellite maps. Logistic and technical support were provided by Doñana ICTS-RBD.

Conflicts of Interest: The authors declare no conflict of interest. The funders had no role in the design of the study; in the collection, analyses, or interpretation of data; in the writing of the manuscript; or in the decision to publish the results.

\section{References}

1. Miles, L.; Newton, A.C.; DeFries, R.S.; Ravilious, C.; May, I.; Blyth, S.; Gordon, J.E. A global overview of the conservation status of tropical dry forests. J. Biogeogr. 2006, 33, 491-505. [CrossRef] 
2. Sanchez-Azofeifa, A.; Powers, J.S.; Fernandes, G.W.; Quesada, M. (Eds.) Tropical Dry Forests in the Americas: Ecology, Conservation, and Management; CRC Press: Boca Raton, FL, USA, 2013.

3. Guevara, J.C.; Grünwaldt, E.G.; Estevez, O.R.; Bisigato, A.J.; Blanco, L.J.; Biurrun, F.N.; Passera, C.B. Range and livestock production in the Monte Desert, Argentina. J. Arid Environ. 2009, 73, 228-237. [CrossRef]

4. Kunst, C.; Ledesma, R.; Bravo, S.; Albanesi, A.; Anriquez, A.; van Meer, H.; Godoy, J. Disrupting woody steady states in the Chaco region (Argentina): Responses to combined disturbance treatments. Ecol. Eng. 2012, 42, 42-53. [CrossRef]

5. Mazzini, F.; Relva, M.A.; Malizia, L.R. Impacts of domestic cattle on forest and woody ecosystems in southern South America. Plant Ecol. 2018, 219, 913-925. [CrossRef]

6. Villagra, P.E.; Defossé, G.E.; Del Valle, H.F.; Tabeni, S.; Rostagno, M.; Cesca, E.; Abraham, E. Land use and disturbance effects on the dynamics of natural ecosystems of the Monte Desert: Implications for their management. J. Arid Environ. 2009, 73, 202-211. [CrossRef]

7. Chillo, V.; Ojeda, R.A. Mammal functional diversity loss under human-induced disturbances in arid lands. J. Arid Environ. 2012, 87, 95-102. [CrossRef]

8. Periago, M.E.; Chillo, V.; Ojeda, R.A. Loss of mammalian species from the South American Gran Chaco: Empty savanna syndrome? Mamm. Rev. 2015, 45, 41-53. [CrossRef]

9. O'Gorman, E.J.; Yearsley, J.M.; Crowe, T.P.; Emmerson, M.C.; Jacob, U.; Petchey, O.L. Loss of functionally unique species may gradually undermine ecosystems. Proc. R. Soc. B Biol. Sci. 2011, 278, 1886-1893. [CrossRef]

10. Borman, M.M. Forest stand dynamics and livestock grazing in historical context. Conserv. Biol. 2005, 19, 1658-1662. [CrossRef]

11. Varela, O.; Bucher, E. The lizard Teius teyou (Squamata: Teiidae) as a legitimate seed disperser in the dry Chaco Forest of Argentina. Stud. Neotrop. Fauna Environ. 2002, 37, 115-117. [CrossRef]

12. Varela, O.; Bucher, E.H. Seed dispersal by Chelonoidis chilensis in the Chaco dry woodland of Argentina. J. Herpetol. 2002, 36, 137-140. [CrossRef]

13. Blanco, G.; Hiraldo, F.; Rojas, A.; Dénes, F.V.; Tella, J.L. Parrots as key multilinkers in ecosystem structure and functioning. Ecol. Evol. 2015, 5, 4141-4160. [CrossRef]

14. Blanco, G.; Tella, J.L.; Díaz-Luque, J.A.; Hiraldo, F. Multiple external seed dispersers challenge the megafaunal syndrome anachronism and the surrogate ecological function of livestock. Front. Ecol. Evol. 2019, 7, 328. [CrossRef]

15. Maldonado, D.E.; Loayza, A.P.; Garcia, E.; Pacheco, L.F. Qualitative aspects of the effectiveness of Culpeo foxes (Lycalopex culpaeus) as dispersers of Prosopis alba (Fabaceae) in a Bolivian dry valley. Acta Oecol. 2018, 87, 29-33. [CrossRef]

16. Tella, J.L.; Hiraldo, F.; Pacífico, E.; Díaz-Luque, J.A.; Dénes, F.V.; Fontoura, F.M.; Guedes, N.; Blanco, G. Conserving the diversity of ecological interactions: The role of two threatened macaw species as legitimate dispersers of "megafaunal" fruits. Diversity 2020, 12, 45. [CrossRef]

17. Janzen, D.H.; Martin, P.S. Neotropical anachronisms: The fruits the gomphotheres ate. Science 1982, 215, 19-27. [CrossRef] [PubMed]

18. Janzen, D.H. Differential seed survival and passage rates in cows and horses, surrogate Pleistocene dispersal agents. Oikos 1982, 38, 150-156. [CrossRef]

19. Jansen, P.A.; Hirsch, B.T.; Emsens, W.J.; Zamora-Gutierrez, V.; Wikelski, M.; Kays, R. Thieving rodents as substitute dispersers of megafaunal seeds. Proc. Natl. Acad. Sci. USA 2012, 109, 12610-12615. [CrossRef] [PubMed]

20. Baños-Villalba, A.; Blanco, G.; Díaz-Luque, J.A.; Dénes, F.V.; Hiraldo, F.; Tella, J.L. Seed dispersal by macaws shapes the landscape of an Amazonian ecosystem. Sci. Rep. 2017, 7, 7373. [CrossRef] [PubMed]

21. Rebein, M.; Davis, C.N.; Abad, H.; Stone, T.; del Sol, J.; Skinner, N.; Moran, M.D. Seed dispersal of Diospyros virginiana in the past and the present: Evidence for a generalist evolutionary strategy. Ecol. Evol. 2017, 7, 4035-4043. [CrossRef]

22. McConkey, K.R.; Nathalang, A.; Brockelman, W.Y.; Saralamba, C.; Santon, J.; Matmoon, U.; Somnuk, R.; Srinoppawan, K. Different megafauna vary in their seed dispersal effectiveness of the megafaunal fruit Platymitra macrocarpa (Annonaceae). PLoS ONE 2018, 13, e0198960. [CrossRef]

23. McRostie, V.B.; Gayo, E.M.; Santoro, C.M.; De Pol-Holz, R.; Latorre, C. The pre-Columbian introduction and dispersal of Algarrobo (Prosopis, Section Algarobia) in the Atacama Desert of northern Chile. PLoS ONE 2017, 12, e0181759. [CrossRef]

24. Burkart, A. A monograph of the genus Prosopis (Leguminosae subfam. Mimosoidae). J. Arnold Arbor. 1976, 57, $219-525$.

25. Galera, F.M. Las Especies del Genero Prosopis (Algarrobos) en América Latina con Especial Énfasis en Aquellas de Interés Económico; FAO/SECYT: Córdoba, Argentina, 2000; Available online: http://www.fao.org/docrep/006/ad314s/ad314s00.HTM (accessed on 6 April 2021).

26. Peinetti, R.; Pereyra, M.; Kin, A.; Sosa, A. Effects of cattle ingestion on viability and germination rate of caldén (Prosopis caldenia) seeds. J. Range Manag. 1993, 46, 483-486. [CrossRef]

27. Villagra, P.E.; Vilela, A.; Giordano, C.; Alvarez, J.A. Ecophysiology of Prosopis species from the arid lands of Argentina: What do we know about adaptation to stressful environments? In Desert Plants; Ramawat, K.G., Ed.; Springer: Berlin/Heidelberg, Germany, 2010; pp. 321-340.

28. Milesi, F.A.; Lopez De Casenave, J. Unexpected relationships and valuable mistakes: Non-myrmecochorous Prosopis dispersed by messy leafcutting ants in harvesting their seeds. Austral Ecol. 2004, 29, 558-567. [CrossRef]

29. Velez, S.; Chacoff, N.P.; Campos, C.M. Seed predation and removal from faeces in a dry ecosystem. Basic Appl. Ecol. 2016, 17, 145-154. [CrossRef] 
30. Giannoni, S.M.; Campos, V.; Andino, N.; Ramos-Castilla, M.; Orofino, A.; Borghi, C.; de Los Rios, C.; Campos, C.M. Hoarding patterns of sigmodontine rodent species in the Central Monte desert (Argentina). Austral Ecol. 2013, 38, 485-492. [CrossRef]

31. Bessega, C.; Vilardi, J.C.; Saidman, B.O. Genetic relationships among American species of the genus Prosopis (Mimosoideae, Leguminosae) inferred from ITS sequences: Evidence for long-distance dispersal. J. Biogeogr. 2006, 33, 1905-1915. [CrossRef]

32. Stoll, A.; Harpke, D.; Schütte, C.; Jimenez, L.; Letelier, L.; Blattner, F.R.; Quandt, D. Landscape genetics of the endangered Atacama Desert shrub Balsamocarpon brevifolium in the context of habitat fragmentation. Glob. Planet. Chang. 2020, 184, 103059. [CrossRef]

33. Villagra, P.E.; Marone, L.; Cony, M.A. Mechanisms affecting the fate of Prosopis flexuosa (Fabaceae, Mimosoideae) seeds during early secondary dispersal in the Monte Desert, Argentina. Austral Ecol. 2002, 27, 416-421. [CrossRef]

34. Pratolongo, P.; Quintana, R.; Malvárez, I.; Cagnoni, M. Comparative analysis of variables associated with germination and seedling establishment for Prosopis nigra (Griseb.) Hieron and Acacia caven (Mol.) Mol. For. Ecol. Manag. 2003, 179, 15-25. [CrossRef]

35. Renison, D.; Valladares, G.; Martella, M.B. The effect of passage through the gut of the Greater Rhea (Rhea americana) on germination of tree seeds: Implications for forest restoration. Emu Austral Ornithol. 2010, 110, 125-131. [CrossRef]

36. Tella, J.L.; Baños-Villalba, A.; Hernández-Brito, D.; Rojas, A.; Pacífico, E.; Díaz-Luque, J.A.; Carrete, M.; Blanco, G.; Hiraldo, F. Parrots as overlooked seed dispersers. Front. Ecol. Environ. 2015, 13, 338-339. [CrossRef]

37. Montesinos-Navarro, A.; Hiraldo, F.; Tella, J.L.; Blanco, G. Network structure embracing mutualism-antagonism continuums increases community robustness. Nat. Ecol. Evol. 2017, 1, 1661. [CrossRef]

38. Catalán, L.; Balzarini, M. Improved laboratory germination condition for several arboreal Prosopis species: P. chilensis, P. flexuosa, P. nigra, P. alba, P. caldenia and P. affinis. Seed Sci. Technol. 1992, 29, 293-298.

39. Vilela, A.E.; Ravetta, D.A. The effect of seed scarification and soil-media on germination, growth, storage, and survival of seedlings of five species of Prosopis, L.(Mimosaceae). J. Arid Environ. 2001, 8, 171-184. [CrossRef]

40. van Klinken, R.D.; Goulier, J.B. Habitat-specific seed dormancy-release mechanisms in four legume species. Seed Sci. Res. 2013, 23, 181-188. [CrossRef]

41. Campos, C.M.; Velez, S. Almacenadores y frugívoros oportunistas: El papel de los mamíferos en la dispersión del algarrobo (Prosopis flexuosa DC) en el desierto del Monte, Argentina. Rev. Ecosist. 2015, 24, 28-34. [CrossRef]

42. Samarah, N.H. Effect of drying methods on germination and dormancy of common vetch (Vicia sativa L.) seed harvested at different maturity stages. Seed Sci. Technol. 2005, 33, 733-740. [CrossRef]

43. Gresta, F.; Avola, G.; Anastasi, U.; Miano, V. Effect of maturation stage, storage time and temperature on seed germination of Medicago species. Seed Sci. Technol. 2007, 35, 698-708. [CrossRef]

44. Angelovici, R.; Galili, G.; Fernie, A.R.; Fait, A. Seed desiccation: A bridge between maturation and germination. Trends Plant Sci. 2010, 15, 211-218. [CrossRef]

45. Klinger, Y.P.; Eckstein, R.L.; Horlemann, D.; Otte, A.; Ludewig, K. Germination of the invasive legume Lupinus polyphyllus depends on cutting date and seed morphology. NeoBiota 2020, 60, 79. [CrossRef]

46. Baskin, C.C.; Baskin, J.M. Seeds: Ecology, Biogeography, and Evolution of Dormancy and Germination; Academic Press: San Diego, CA, USA, 2014.

47. Fenner, M.K.; Fenner, M.; Thompson, K. The Ecology of Seeds; Cambridge University Press: Cambridge, UK, 2005.

48. Barnett, A.A.; Boyle, S.A.; Pinto, L.P.; Lourenço, W.C.; Almeida, T.; Silva, W.S.; Spironello, W.R. Primary seed dispersal by three Neotropical seed-predating primates (Cacajao melanocephalus ouakary, Chiropotes chiropotes and Chiropotes albinasus). J. Trop. Ecol. 2012, 28, 543-555. [CrossRef]

49. Blanco, G.; Hiraldo, G.; Tella, J.L. Ecological functions of parrots: An integrative perspective from plant life cycle to ecosystem functioning. Emu Austral Ornithol. 2018, 118, 36-49. [CrossRef]

50. Sebastián-González, E.; Hiraldo, F.; Blanco, G.; Hernández-Brito, D.; Romero-Vidal, P.; Carrete, M.; Gómez-Llanos, E.; Pacífico, E.; Díaz-Luque, J.A.; Denés, F.V.; et al. The extent, frequency and ecological functions of food wasting by parrots. Sci. Rep. 2019, 9 , 15280. [CrossRef]

51. Tella, J.L.; Blanco, G.; Dénes, F.V.; Hiraldo, F. Overlooked parrot seed dispersal in Australia and South America: Insights on the evolution of dispersal syndromes and seed size in Araucaria trees. Front. Ecol. Evol. 2019, 7, 82. [CrossRef]

52. Young, L.M.; Kelly, D.; Nelson, X.J. Alpine flora may depend on declining frugivorous parrot for seed dispersal. Biol. Conserv. 2012, 147, 133-142. [CrossRef]

53. Blanco, G.; Bravo, C.; Pacífico, E.; Chamorro, D.; Speziale, K.; Lambertucci, S.; Hiraldo, F.; Tella, J.L. Internal seed dispersal by parrots: An overview of a neglected mutualism. PeerJ 2017, 4, e1688. [CrossRef]

54. Blanco, G.; Bravo, C.; Chamorro, D.; Lovas-Kiss, A.; Hiraldo, F.; Tella, J.L. Herb endozoochory by cockatoos: Is "foliage the fruit"? Austral Ecol. 2020, 45, 122-126. [CrossRef]

55. Bravo, C.; Chamorro, D.; Hiraldo, F.; Speziale, K.; Lambertucci, S.A.; Tella, J.L.; Blanco, G. Physiological dormancy broken by endozoochory: Austral parakeets (Enicognathus ferrugineus) as legitimate dispersers of Calafate (Berberis microphylla) in the Patagonian Andes. J. Plant Ecol. 2020, 13, 538-544. [CrossRef]

56. Hernández-Brito, D.; Romero-Vidal, P.; Hiraldo, F.; Blanco, G.; Díaz-Luque, J.A.; Barbosa, J.; Symes, C.; White, T.W.; Pacifico, E.G.; Sebastián-González, E.; et al. Epizoochory in parrots as an overlooked yet widespread plant-animal mutualism. Plants 2021, 10, 760. [CrossRef]

57. Tella, J.L.; Dénes, F.V.; Zulian, V.; Prestes, N.P.; Martínez, J.; Blanco, G.; Hiraldo, F. Endangered plant-parrot mutualisms: Seed tolerance to predation makes parrots pervasive dispersers of the Parana pine. Sci. Rep. 2016, 6, 31709. [CrossRef] [PubMed] 
58. Cabrera, A.L. Regiones fitogeográficas argentinas. In Enciclopedia Argentina de Agricultura y Jardinería; Editorial Acme: Buenos Aires, Argentina, 1976; Volume 2, pp. 1-85.

59. Labraga, J.C.; Villalba, R. Climate in the Monte Desert: Past trends, present conditions, and future projections. J. Arid Environ. 2009, 73, 154-163. [CrossRef]

60. Salfity, J.A. Geología regional del Valle Calchaquí, Argentina. Anal. Acad. Nac. Cien. Exact. Fis. Nat. 2004, 56, 133-150.

61. Varela Ituarte, M.A.; Perea, M.C.; Neder, L.D.V.; Rios, R.D.V. Unidades del Paisaje del valle de Santa María, Cafayate (Salta, Argentina). Rev. Asoc. Argent. Ecol. Paisajes 2018, 8, 1-16.

62. Godoy-Bürki, A.C.; Biganzoli, F.; Sajama, J.M.; Ortega-Baes, P.; Aagesen, L. Tropical high Andean drylands: Species diversity and its environmental determinants in the Central Andes. Biodivers. Conserv. 2017, 26, 1257-1273. [CrossRef]

63. Fontana, M.L.; Pérez, V.R.; Luna, C.V. Características evolutivas en Prosopis spp., citogenética, genética e hibridaciones. Rodriguésia 2018, 69, 409-421. [CrossRef]

64. Hunziker, J.H.; Poggio, L.; Naranjo, C.A.; Palacios, R.A.; Andrada, A.B. Cytogenetic of some species and natural hybrids in Prosopis (Leguminosae). Can. J. Gen. Cytol. 1975, 17, 253-262. [CrossRef]

65. Ramírez, L.; de la Vega, A.; Razkin, N.; Luna, V.; Harris, P.J. Analysis of the relationships between species of the genus Prosopis revealed by the use of molecular markers. Agronomie 1999, 19, 31-43. [CrossRef]

66. Giamminola, E.M.; Viana, M.L. Caracterización morfológica de frutos y semillas de dos accesiones de Prosopis nigra (Griseb.) Hieron. Y Cesalpinia paraguarensis (D.Parodi) Burkart., conservadas en el Banco de Germoplasma de Especies Nativas de la Universidad Nacional de Salta, Argentina. Lhawet Nuestro Entorno 2013, 2, 23-29.

67. Prokopiuk, D.; Cruz, G.; Grados, N.; Garro, O. Estudio comparativo entre frutos de Prosopis alba y Prosopis pallida. Multequina 2000, 9, 35-45.

68. Sciammaro, L.; Ferrero, C.; Puppo, C. Agregado de valor al fruto de Prosopis alba. Estudio de la composición química y nutricional para su aplicación en bocaditos dulces saludables. Rev. Agronom. La Plata 2015, 114, 115-123.

69. Velez, S.; Chacoff, N.P.; Campos, C.M. Pre-dispersal seed loss in two Prosopis species (Fabacea: Mimosoidea) from the Monte Desert, Argentina. Ecol. Austral 2018, 28, 361-373. [CrossRef]

70. Campos, C.M.; Ojeda, R.A. Dispersal and germination of Prosopis flexuosa (Fabaceae) seeds by desert mammals in Argentina. J. Arid Environ. 1997, 35, 707-714. [CrossRef]

71. Campos, C.M.; Giannoni, S.M.; Taraborelli, P.; Borghi, C.E. Removal of mesquite seeds by small rodents in the Monte desert, Argentina. J. Arid Environ. 2007, 69, 228-236. [CrossRef]

72. Masello, J.F.; Quillfeldt, P.; Munimanda, G.K.; Klauke, N.; Segelbacher, G.; Schaefer, H.M.; Moodley, Y. The high Andes, gene flow and a stable hybrid zone shape the genetic structure of a wide-ranging South American parrot. Front. Zool. 2011, 8, 1-17. [CrossRef] [PubMed]

73. Masello, J.F.; Quillfeldt, P. ¿Cómo reproducirse exitosamente en un ambiente cambiante? Biología reproductiva del Loro Barranquero (Cyanoliseus patagonus) en el noreste de la Patagonia. Hornero 2012, 27, 73-88.

74. BirdLife International. Cyanoliseus patagonus. The IUCN Red List of Threatened Species. Available online: 2018:e.T22685779A132 255876. (accessed on 6 April 2021).

75. Vargas-Rodríguez, R.; Squeo, F.A. Historia Natural del Loro Tricahue en el Norte de Chile; Universidad de La Serena Press: La Serena, Chile, 2014.

76. Masello, J.F.; Pagnossin, M.L.; Sommer, C.; Quillfeldt, P. Population size, provisioning frequency, flock size and foraging range at the largest known colony of Psittaciformes: The Burrowing Parrots of the north-eastern Patagonian coastal cliffs. Emu Austral Ornithol. 2006, 106, 69-79. [CrossRef]

77. Sánchez, R.; Ballari, S.A.; Bucher, E.H.; Masello, J.F. Foraging by burrowing parrots has little impact on agricultural crops in northeastern Patagonia, Argentina. Int. J. Pest Manag. 2016, 62, 326-335. [CrossRef]

78. Romero-Vidal, P.; Hiraldo, F.; Rosseto, F.; Blanco, G.; Carrete, M.; Tella, J.L. Opportunistic or Non-Random Wildlife Crime? Attractiveness rather than Abundance in the Wild Leads to Selective Parrot Poaching. Diversity 2020, 12, 314. [CrossRef]

79. Tella, J.L.; Romero-Vidal, P.; Dènes, F.V.; Hiraldo, F.; Toledo-González, B.; Rossetto, F.; Blanco, G.; Hernández-Brito, D.; Pacífico, E.; Díaz, J.A.; et al. Roadside car surveys: Methodological constraints and solutions for estimating parrot abundances across the world. Diversity 2021. (in review).

80. Hadfield, J.D. MCMC methods for multi-response generalized linear mixed models: The MCMCglmm R package. J. Stat. Softw. 2010, 33, 1-22. [CrossRef]

81. Moore, R.P. Handbook on Tetrazolium Testing; The International Seed Testing Association: Zurich, Switzerand, 1985.

82. Grilli, P.G.; Soave, G.E.; Arellano, M.L.; Masello, J.F. Abundancia relativa del Loro Barranquero (Cyanoliseus patagonus) en la provincia de Buenos Aires y zonas limítrofes de La Pampa y Río Negro, Argentina. Hornero 2012, $27,63-71$.

83. Kissling, W.D.; Bohning-Gaese, K.; Jetz, W. The global distribution of frugivory in birds. Glob. Ecol. Biogeogr. 2009, 18, 150-162. [CrossRef]

84. Renton, K. Lilac-crowned parrot diet and food resource availability: Resource tracking by a parrot seed predator. Condor 2001, 103, 62-69. [CrossRef]

85. Selman, R.G.; Hunter, M.L.; Perrin, M.R. The feeding ecology of Ruppell's parrot Poicephalus rueppellis in Namibia. Ostrich 2002, 73, 127-134. [CrossRef] 
86. Boyes, R.S.; Perrin, M.R. The feeding ecology of Meyer's parrot, Poicephalus meyeri, in the Okavango Delta, Botswana. Ostrich 2009, 80, 153-164. [CrossRef]

87. White, T.C. The significance of unripe seeds and animal tissues in the protein nutrition of herbivores. Biol. Rev. 2011, 86, 217-224. [CrossRef] [PubMed]

88. Nuevo, Á. Manual Técnico de Dietología de Papagayos; Castel Negrino: Aicurzio, Italy, 2015.

89. Catalano, S.A.; Vilardi, J.C.; Tosto, D.; Saidman, B.O. Molecular phylogeny and diversification history of Prosopis (Fabaceae: Mimosoideae). Biol. J. Linn. Soc. 2008, 93, 621-640. [CrossRef]

90. Masello, J.F.; Montano, V.; Quillfeldt, P.; Nuhlíčková, S.; Wikelski, M.; Moodley, Y. The interplay of spatial and climatic landscapes in the genetic distribution of a South American parrot. J. Biogeogr. 2015, 42, 1077-1090. [CrossRef]

91. Luebert, F.; Weigend, M. Phylogenetic insights into Andean plant diversification. Front. Ecol. Evol. 2014, 2, 27. [CrossRef]

92. Campos, C.M.; Peco, B.; Campos, E.; Malo, J.E.; Giannoni, S.M.; Suárez, F. Endozoochory by native and exotic herbivores in dry areas: Consequences for germination and survival of Prosopis seeds. Seed Sci. Res. 2008, 18, 91-100. [CrossRef]

93. Campos, C.M.; Campos, V.E.; Mongeaud, A.; Borghi, C.E.; De los Rios, C.; Giannoni, S.M. Relationships between Prosopis flexuosa (Fabaceae) and cattle in the Monte desert: Seeds, seedlings and saplings on cattle-use site classes. Rev. Chil. Hist. Nat. 2011, 84, 289-299. [CrossRef]

94. Vander Wall, S.B.; Longland, W.S. Diplochory: Are two seed dispersers better than one? Trends Ecol. Evol. 2004, 19, 155-161. [CrossRef] [PubMed]

95. Robertson, A.W.; Trass, A.; Ladley, J.J.; Kelly, D. Assessing the benefits of frugivory for seed germination: The importance of the deinhibition effect. Funct. Ecol. 2006, 20, 58-66. [CrossRef]

96. Marone, L.; Horno, M.; González del Solar, R. Postdispersal fate of seeds in the Monte desert of Argentina: Patterns of germination in successive wet and dry years. J. Ecol. 2000, 88, 940-949. [CrossRef] 